\title{
Tropospheric ozone maxima observed over the Arabian Sea during the pre-monsoon
}

\author{
Jia Jia $^{1}$, Annette Ladstätter-Weißenmayer ${ }^{1}$, Xuewei Hou ${ }^{2}$, Alexei Rozanov ${ }^{1}$, and John P. Burrows ${ }^{1}$ \\ ${ }^{1}$ Institute of Environmental Physics, Bremen, Germany \\ ${ }^{2}$ Nanjing University of Information Science and Technology, Nanjing, China \\ Correspondence to: Jia Jia (jia@iup.physik.uni-bremen.de)
}

Received: 30 August 2016 - Discussion started: 20 October 2016

Revised: 13 March 2017 - Accepted: 14 March 2017 - Published: 18 April 2017

\begin{abstract}
An enhancement of the tropospheric ozone column (TOC) over Arabian Sea (AS) during the pre-monsoon season is reported in this study. The potential sources of the AS spring ozone pool are investigated by use of multiple data sets (e.g., SCIAMACHY Limb-Nadir-Matching TOC, OMI/MLS TOC, TES TOC, MACC reanalysis data, MOZART-4 model and HYSPLIT model). Three-quarters of the enhanced ozone concentrations are attributed to the $0-8 \mathrm{~km}$ height range. The main source of the ozone enhancement is considered to be caused by long-range transport of ozone pollutants from India ( $\sim 50 \%$ contributions to the lowest $4 \mathrm{~km}, \sim 20 \%$ contributions to the $4-8 \mathrm{~km}$ height range), the Middle East, Africa and Europe ( $\sim 30 \%$ in total). In addition, the vertical pollution accumulation in the lower troposphere, especially at 4-8 km, was found to be important for the AS spring ozone pool formation. Local photochemistry, on the other hand, plays a negligible role in producing ozone at the $4-8 \mathrm{~km}$ height range. In the $0-4 \mathrm{~km}$ height range, ozone is quickly removed by wet deposition. The AS spring TOC maxima are influenced by the dynamical variations caused by the sea surface temperature (SST) anomaly during the El Niño period in 2005 and 2010 with a 5 DU decrease.
\end{abstract}

\section{Introduction}

Tropospheric ozone is one of the most important greenhouse gases and one of the most important components of photochemical smog. Most tropospheric ozone is produced in situ by photochemical reactions of its precursors $\left(\mathrm{NO}_{x}(\mathrm{NO}+\right.$ $\left.\mathrm{NO}_{2}\right) ; \mathrm{CO} ; \mathrm{CH}_{4}$; and volatile organic compounds, VOCs) in the presence of sunlight, while some tropospheric ozone naturally originates in the stratosphere. High surface ozone values are detrimental to human health by causing respiratory illnesses, and can also lead to losses in agricultural crops (see Van Dingenen et al., 2009; Mills et al., 2016, and references therein).

In this study, we investigated the global pattern of tropospheric ozone by averaging 7 years (2005-2011) of Tropospheric Ozone Column (TOC) data products from different satellite instrumentation: SCIAMACHY Limb-NadirMatching TOC (Ebojie et al., 2014; Jia, 2016) and the OMI/MLS TOC (Ziemke et al., 2006). A tropospheric ozone maximum is observed over the Arabian Sea (AS, west side of the subcontinental India). This enhancement of TOC can be observed in yearly mean image as well (Fig. 1). The enhancement of TOC is similar in magnitude as TOC enhancements observed during the follow events: (1) the wellknown biomass burning plume in the Southern Hemisphere that was transported over the South Atlantic, the coast of South Africa, along the Indian Ocean and towards Australia (e.g., Fishman et al., 1986, 1991); (2) TOC attributed to anthropogenic sources in the Northern Hemisphere, for instance northern India; and (3) the Mediterranean summer ozone pool attributed to the stratospheric-tropospheric exchange (STE) (Zanis et al., 2014). A spring (or so-called pre-monsoon; see Sect. 2.1) TOC maximum of $\sim 42 \mathrm{DU}$ on monthly average was identified from our study of the seasonality of the TOC. Although the TOC enhancement over AS is an important global pattern of tropospheric ozone, the spring maxima in TOC are not unique over the AS representing rather a well-known large-scale phenomenon in the Northern Hemisphere. Nevertheless, the origin and mecha- 
nisms explaining this phenomenon is still a matter for debate (e.g. Monks, 2000; Monks et al., 2015, and references therein). The increase of tropospheric pollutants, presumably increase of longer-lived VOCs which are ozone precursors, during winter, may play an important role by influencing the two major contributors to tropospheric ozone concentrations: the STE intrusions and the photochemical production process (Holton et al., 1995; Penkett et al., 1998; Monks, 2000). In a remote region like AS, an intuitive hypothesis is that longrange transport (LRT) of ozone from more polluted regions or from STE may be the drivers. This is because of the longer ozone lifetime in spring and the weak local production over remote areas (Wang et al., 1998).

In previous studies using the ozonesonde measurements above the west coast of India and the data from two campaigns (the 1998 and 1999 INDian Ocean EXperiment (INDOEX) campaigns and the Integrated Campaign for Aerosols, Gases and Radiation Budget (ICARB) campaign, which was conducted during March-May 2006), the higher AS TOC during pre-monsoon season was confirmed to be significantly influenced by LRT of the continental anthropogenically influenced outflows from the Middle East, western India, Africa, North America and Europe (Lal and Lawrence, 2001; Chand et al., 2003; Srivastava et al., 2011, 2012; Lal et al., 2013, 2014). In addition, by comparing the INDOEX ozone measurements from both sides (northern and southern) of the ITCZ (Intertropical Convergence Zone), the influence of the ITCZ functioning as a sink for ozone was determined by the observed 4 times higher TOC values on the northern side of AS compared to the southern side (Chand et al., 2003). The seasonal variation in tropospheric ozone at Ahmadabad $\left(23.03^{\circ} \mathrm{N}, 72.54^{\circ} \mathrm{E}\right)$ was reported to have an averaged maximum of $\sim 44$ DU in April during the years 20032007 (Lal et al., 2014). The possibility of the STE influencing the ozone mixing ratio up to $\sim 10 \mathrm{~km}$ altitude was also discussed. However, the mechanisms explaining this phenomenon need to be better understood.

Here, the TOC enhancement over the AS is investigated and interpreted by using TOC data products from several satellite remote sensors (i.e. SCIAMACHY Limb-Nadir Matching, OMI/MLS and TES), MACC (Monitoring Atmospheric Composition and Climate) reanalysis data (Inness et al., 2013) and simulations from the global tropospheric chemical transport model (CTM) MOZART-4 model (Model for Ozone and Related Tracers) (Emmons et al., 2010). This study focuses on the analysis of the regional contribution to LRT, the influence of the meteorological conditions, the local chemistry and STE, and the inter-annual variability in the spring ozone maxima in order to better understand the climate interact with the distribution of tropospheric ozone through temperature, humidity and dynamics. In Sect. 2, the data sets used in this study are briefly discussed. In Sect. 3, the regional distribution and the time series of tropospheric ozone and its precursors are investigated. Meteorological and photochemical sources of ozone plumes due to LRT, local chemistry and STE are discussed in Sect. 4. The role of accumulation of pollutants is also highlighted in this section. In Sect. 5 the impact of El Niño on the inter-annual variability is identified. Finally, conclusions are given in Sect. 6 .

\section{Data sets used in this study}

The SCanning Imaging Absorption spectroMeter for Atmospheric CHartographY (SCIAMACHY) was a passive spectrometer designed to measure radiances in eight spectral channels, covering a wide range from 214 to $2384 \mathrm{~nm}$ with a moderate spectral resolution of 0.21 to $1.56 \mathrm{~nm}$ (Burrows et al., 1995; Bovensmann et al., 1999). SCIAMACHY performed observations in three viewing modes: nadir, limb and solar/lunar occultation. The SCIAMACHY Limb-NadirMatching TOC is retrieved based on the tropospheric ozone residual (TOR) method, which subtracts the stratospheric ozone columns retrieved from the limb measurements, from the collocated total ozone columns acquired from nadir measurements, by using the tropopause height data (Ebojie et al., 2014). The results showed in this study are from the V1.2 SCIAMACHY Limb-Nadir-Matching TOC data set. This data set is recently developed in the Institute of Environmental Physics (IUP) in the University of Bremen (Details can be found in Jia, 2016). The data set is not complete in a full SCIAMACHY performing time period (2002-2012), thus is not showed in the time series image.

The UV-visible nadir-viewing spectrometer Ozone Monitoring Instrument (OMI), the thermal-emission Microwave Limb Sounder (MLS) and the infrared Fourier transform spectrometer Tropospheric Emission Spectrometer (TES) are three of the main instruments onboard the EOS Aura satellite (Levelt et al., 2006; Waters et al., 2006; Beer, 2006). The OMI/MLS TOC data set is retrieved based on the TOR method using data sets from OMI and MLS. The adjustment for inter-calibration differences of OMI and MLS instruments is performed by using the CCD method (Ziemke et al., 2006, 2011). Both OMI-CCD and MLS measurements of the stratospheric ozone are averaged for the comparison over the Pacific $\left(120^{\circ} \mathrm{W}-120^{\circ} \mathrm{E}\right)$ (Ziemke et al., 2006). The MLS data are adjusted according to the observed differences, and then interpolated in two steps along track and along longitude. In the end, OMI/MLS is able to provide daily-based global TOCs.

TES ozone is retrieved from the $9.6 \mu \mathrm{m}$ ozone absorption band using the $995-1070 \mathrm{~cm}^{-1}$ spectral range. In cloud-free conditions, the nadir vertical profiles have around four degrees of freedom (DOF) for signal, approximately two of which are in the troposphere, giving an estimated vertical resolution of about $6 \mathrm{~km}$ with a footprint of $5.3 \mathrm{~km} \times 8.5 \mathrm{~km}$, covering an altitude range of $0-33 \mathrm{~km}$ (see Beer et al., 2001; Nassar et al., 2008 and the references therein).

MACC is a research project for the European GMES (Global Monitoring for Environment and Security) initia- 


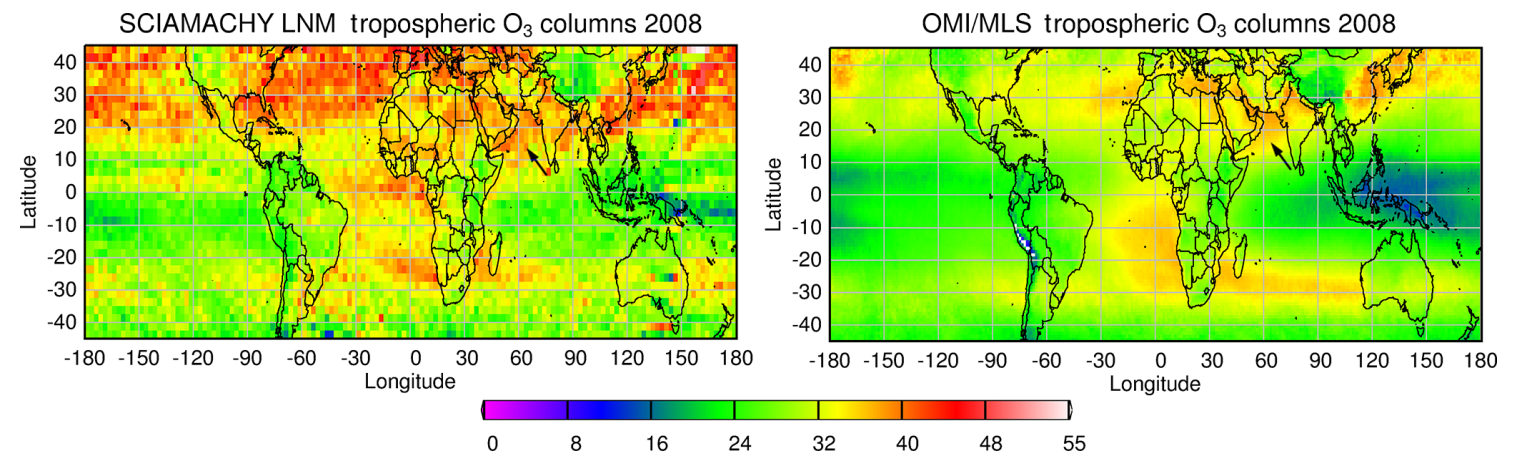

Figure 1. Yearly average for TOC retrieved from (left) SCIAMACHY LNM and (right) OMI/MLS in 2008, with bold arrows pointing to AS. The AS region is defined as $10-20^{\circ} \mathrm{N}, 60-70^{\circ} \mathrm{E}$ in this study and is marked with a red rectangle in Fig. 2.

tive (Inness et al., 2013). MACC combines a wealth of atmospheric composition data with a state-of-the-art numerical model and data assimilation system to produce a reanalysis of the atmospheric composition. MACC reanalysis data of ozone, $\mathrm{CO}$ and specific humidity used in this study are available in $6 \mathrm{~h}$ time intervals (00:00, 06:00, 12:00 and 18:00 UTC) and were provided in monthly files with the unit of $\mathrm{kg} / \mathrm{kg}$ under the website http://apps.ecmwf.int/datasets/ data/macc-reanalysis/levtype $=\mathrm{ml} /$. The horizontal resolution of the model is $1.125^{\circ} \times 1.125^{\circ}$. Variables were provided as 3 -D fields in pressure hybrid vertical coordinates. The vertical coordinate system is given by 60 hybrid sigma-pressure levels, with a model top at $0.1 \mathrm{hPa}$.

MOZART-4 is a global tropospheric CTM. It was run with the standard chemical mechanism (see Emmons et al., 2010, for details) in this study. MOZART-4 was driven by the National Centers for Environmental Prediction (NCEP)/National Center for Atmospheric Research (NCAR) reanalysis meteorological parameters, having a horizontal resolution of approximately $2.8^{\circ} \times 2.8^{\circ}$, with 28 vertical levels from the surface to approximately $2 \mathrm{hPa}$. The data used in this study are simulation results obtained by Zhu et al. (2016), using MOZART-4 model for 1997-2007. The chemical initial condition in 2000 and emissions from 1997 to 2007 used in MOZART-4 were from the NCAR Community Data Portal (http://cdp.ucar.edu/), which was introduced by Emmons et al. (2010). The model was run with a time step of $20 \mathrm{~min}$ from 1 January 1996 to 31 December 2007, and the first year was discarded as spin-up (Hou et al., 2014; Zhu et al., 2016). The tagged tracer method was used to isolate the contributions from individual source regions. This method was introduced by Sudo and Akimoto (2007). It treats a chemical species emitted or chemically produced in a certain region as a separate tracer and calculates its transport, chemical transformation and surface deposition. More details of the simulation settings can be found in Hou et al. (2014).

HYbrid Single-Particle Lagrangian Integrated Trajectory (HYSPLIT) is a system for the computation of simple air parcel trajectories from the National Oceanic and Atmospheric
Administration (NOAA). In order to investigate the forward and backward trajectory of the air mass, the web-based version of the HYSPLIT model (Stein et al., 2015) is used for this study: http://ready.arl.noaa.gov/hypub-bin/trajtype. pl? runtype $=$ archive.

\section{Observation of a pre-monsoon enhancement in TOC data products}

Satellite-retrieved TOCs have a better spatial and temporal coverage compared to ozonesonde measurements. However in situ measurements of ozone from ozonesondes are considered more accurate. Combining the two types of measurements provides an opportunity to investigate data-sparse regions such as the AS. In comparison with the studies using ozonesonde and ship measurements, the analysis of the satellite observations of TOCs regarding AS region is still a gap in the current state. In this section, the satellite observations and the model results are presented.

Figure 2 shows the regional distribution of the TOC and two of its photochemical precursors: $\mathrm{NO}_{2}$ and $\mathrm{CO}$. Seasonal cycles of TOC, $\mathrm{CO}$ and $\mathrm{NO}_{2}$ over the AS are shown in Fig. 3. A seasonal pattern of TOC is observed in both OMI/MLS and TES. An offset of $\sim 5 \mathrm{DU}$ exists between the two investigated TOC data products. A maximum of TOC over AS is observed ( $\sim 42 / 47$ DU) in every April during the years 20052012 , followed by monsoon/summer minima of $\sim 20 \mathrm{DU}$. TOC recovers to $\sim 35 \mathrm{DU}$ in the post-monsoon autumn but drops down slightly during the winter monsoon. This seasonal pattern is consistent with the results from the sonde station Ahmedabad (Fig. 6 in Lal et al., 2014) and depends on the meteorological conditions (Sect. 3.1). The spring TOC is higher over western AS than over eastern AS (Fig. 2). This distribution is further discussed in Sect. 4.2. The ozone precursors, $\mathrm{CO}$ and $\mathrm{NO}_{2}$, show a different behaviour than ozone. As $\mathrm{NO}_{2}$ has a short lifetime (2-8h; Beirle et al., 2011), the tropospheric $\mathrm{NO}_{2}$ data products, retrieved from observations of SCIAMACHY or other related instrumentation in space, show high values over anthropogenic sources and rel- 

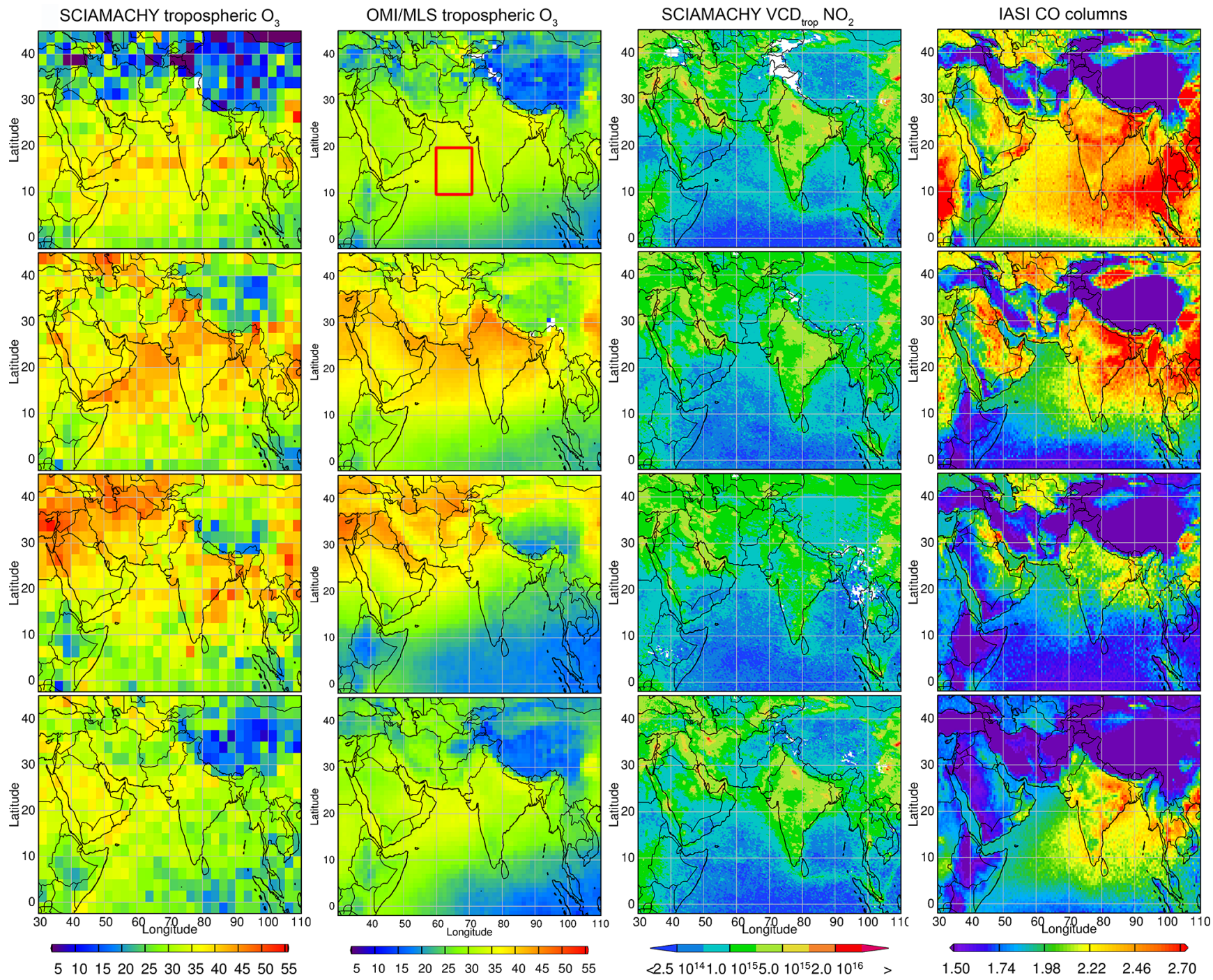

Figure 2. Plots of the TOC and $\mathrm{NO}_{2}$ (Hilboll et al., 2013) and $\mathrm{CO}\left(\times 10^{18}\right.$; George et al., 2009) as a function of season in 2008. The unit for TOC is DU and that for $\mathrm{NO}_{2}$ and CO in molec $\mathrm{cm}^{-2}$. From top to bottom are DJF (December to February), MAM (March to May), JJA (June to August) and SON (September to November).

atively low values, often below the detection limit, over the remote regions. Over the AS, tropospheric $\mathrm{NO}_{2}$ columns are small, being around $10^{14}$ molec $\mathrm{cm}^{-2}$. This small concentration originates from ship emissions and continental outflow (Richter et al., 2004). Higher values can be observed during the winter monsoon from transport off the Asian coast. CO has a longer lifetime than ozone $(\sim 2$ months on average for $\mathrm{CO}$ and $\sim 23$ days for tropospheric ozone; Novelli et al., 1998; Young et al., 2013). Due to the relatively long lifetime of $\mathrm{CO}$ and ozone, both trace gases show a similar transport pattern. For instance, the biomass burning plume originating from southern Africa in boreal autumn in the Southern Hemisphere can be observed as well for $\mathrm{CO}$ as for ozone. However, in comparison to ozone, which is produced due to the photochemical production, the spatial pattern of $\mathrm{CO}$ is known to be more driven by emissions than dynamical processes (Logan et al., 2008). Thus, the time series of the data products for tropospheric $\mathrm{CO}$ reveals a similar winter maximum as $\mathrm{NO}_{2}$, and it also shows a smaller peak in spring time as TOC. The spring peaks of $\mathrm{CO}$ are observed one month earlier than that those of TOC. This shift can be caused by the combustion emission of CO in southern Asia (Fig. 6 in Duncan et al., 2003). The different spatial distribution among ozone precursors and ozone indicates a dynamic origin for high TOC over AS from long-range transport of ozone.

In this paper, MACC reanalysis data are used to provide vertical information of ozone. This choice is motivated by the fact that OMI and MLS satellite ozone data were actively assimilated in the MACC reanalysis and constrain tropospheric ozone (Inness et al., 2013). Figure 4 shows MACC results 

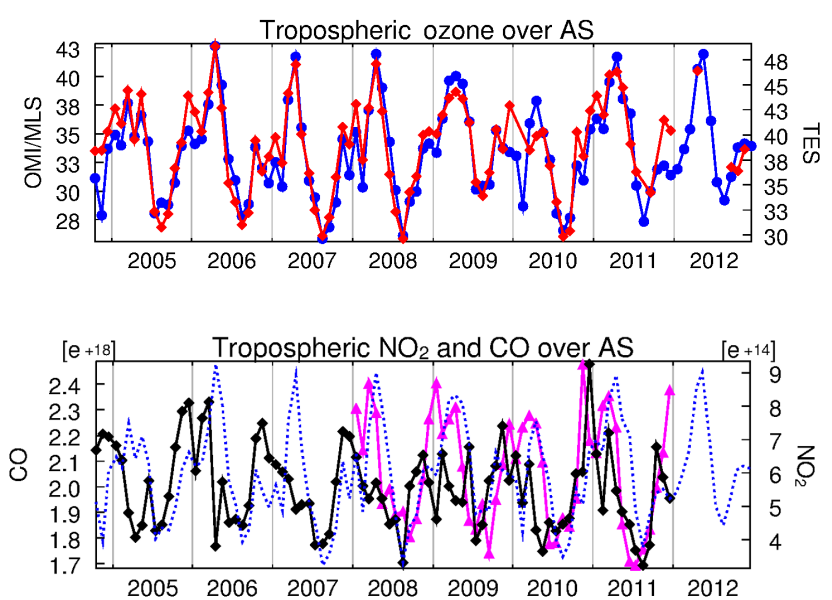

Figure 3. Trace gas time series over AS $\left(10-20^{\circ} \mathrm{N}, 60-70^{\circ} \mathrm{E}\right)$ from 2004 to 2012. The blue (solid and dotted) curves represent OMI/MLS ozone, red is TES ozone, magenta is IASI CO and black stands for SCIAMACHY $\mathrm{NO}_{2}$. The vertical columns are given in DU for ozone and molec $\mathrm{cm}^{-2}$ for $\mathrm{NO}_{2}$ and $\mathrm{CO}$. The region used for this time series calculation is marked with a red rectangle in Fig. 2. The time series of TOC from SCIAMACHY, MACC, OMI.MLS and TES in the year 2008 is presented in Appendix Fig. A3.

of ozone partial columns between $0 \mathrm{~km}$ and the tropopause height (TPH), determined from ECMWF retrieval (Ebojie et al., 2014), and between 0 and $8 \mathrm{~km}$. In a year with no ENSO (El Niño-Southern Oscillation) event in spring, for instance in 2006 (upper panels of Fig. 4), the enhanced ozone during pre-monsoon is $\sim 30 \mathrm{DU}$ out of $\sim 40 \mathrm{DU}(\sim 3 / 4)$ originating from the lower troposphere $(0-8 \mathrm{~km})$. Because of this result, possible origins will be discussed in the following section (Sect. 3) by analysing four various altitude ranges: 0-4, 4-8, $8-12$ and $12-18 \mathrm{~km}$.

\section{Potential origins of the AS pre-monsoon ozone pool}

\subsection{Influences of meteorology}

The AS region is defined in this study as $10-20^{\circ} \mathrm{N}, 60-$ $70^{\circ} \mathrm{E}$ on the west side of subcontinental India. This location is influenced by the tropical/subtropical air mass exchanges and the sea breeze circulation (e.g., Lawrence and Lelieveld, 2010). The climate of AS can be divided into four different seasons, due to the seasonal variation in the ITCZ: winterspring monsoon (December-February), pre-monsoon transition (March-May), summer monsoon (June-August), and post-monsoon transition (September-November). In summer, the ITCZ is at its northernmost position. The wind appears to be westerly and strong due to the Somali jet (Fig. 5). This condition causes strong precipitation, higher cloud cover frequency and increased air humidity over AS (David and Nair, 2013). The wind and strong precipitation
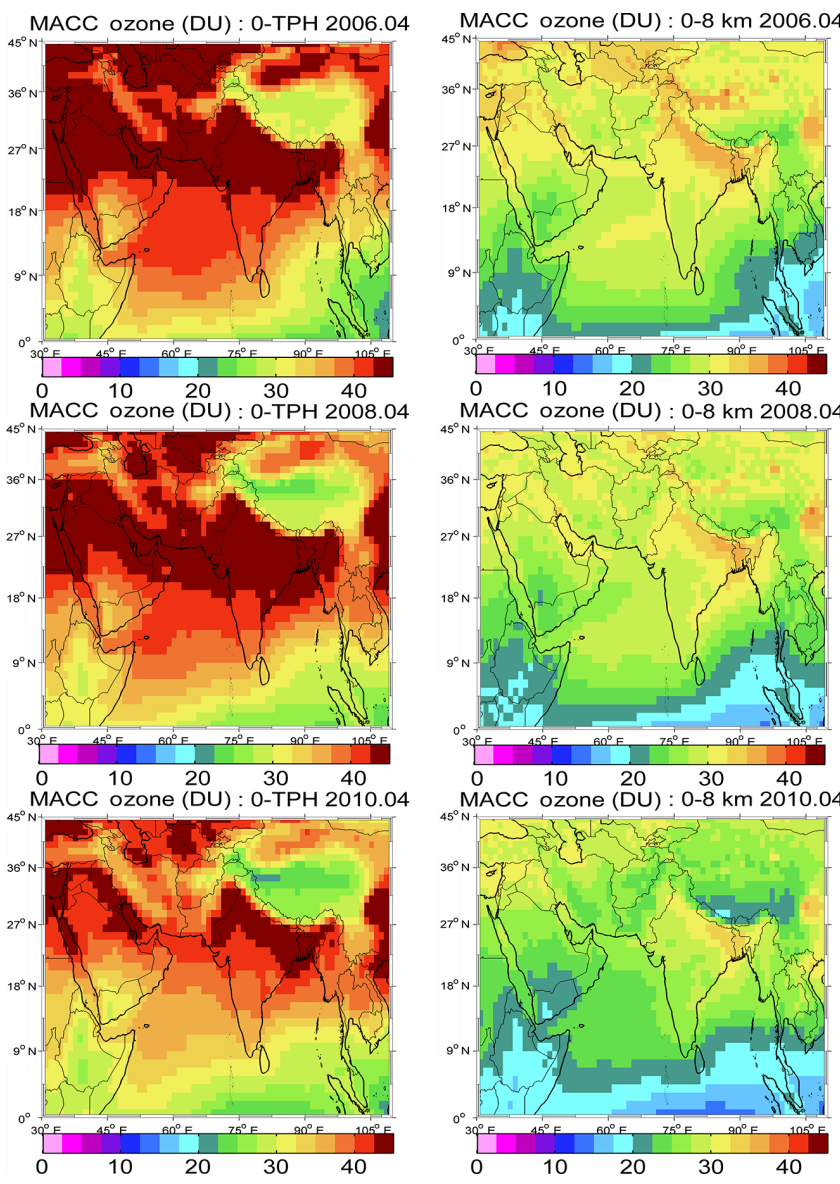

Figure 4. Ozone partial columns (TOC: $0 \mathrm{~km}-\mathrm{TPH}(\sim 17 \mathrm{~km}$ over AS) column of tropospheric ozone in the left panels and $0-8 \mathrm{~km}$ column of tropospheric ozone in the right panels) from MACC reanalysis model in April 2006 (upper panels), 2008 (middle panels) and 2010 (lower panels).

"wash" the air masses and remove soluble pollutants. A summer monsoon minimum for the trace gases such as shown in Fig. 3 may be expected. The destruction of ozone by reactive halogens is another potential sink for the ozone in the marine boundary layer (Dickerson et al., 1999; Ali et al., 2009). During the pre-monsoon transition, surface winds are westerly at the northern AS with an anticyclonic pattern centred over the middle AS. At this time, the AS is most of the time cloud-free and dynamically steady. This cloud-free anticyclonic condition possibly causes subsidence of air masses and results in accumulation of pollutants (Sect. 3.2). The ITCZ located at the southern part of the AS can become the "border" that stops the pollutants (in this case, tropospheric ozone) diffusing to the Indian Ocean with ozone depletion on the surface of cloud droplets in the convective region (Lelieveld and Crutzen, 1990).

It is worth mentioning that the solar radiation over the AS, unlike in the middle/high latitudes, where it is strongest in summer, reaches its maximum during pre-monsoon (Weller 

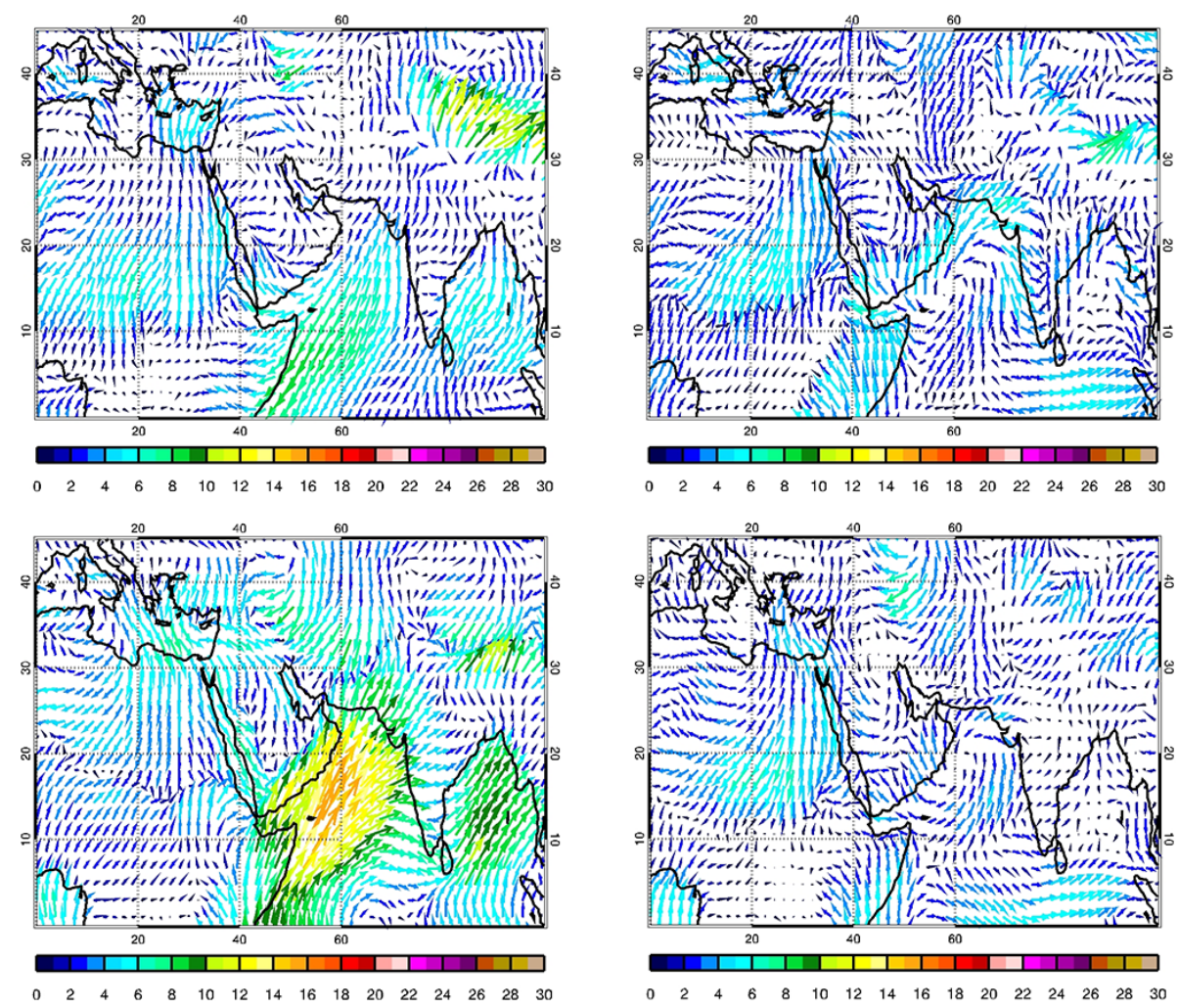

Figure 5. Ten-metre sea surface wind on January (upper left), April (upper right), July (lower left) and October (lower right) over AS at 2008 from NCEP (National Centers for Environmental Prediction). Figure provided by Anne Blechschmidt from the University of Bremen.

et al., 1998; David and Nair, 2013). One could argue that a maximum solar radiation can cause stronger photochemical reactions and thus an increased ozone concentration. To answer this question, the contribution of the photochemical production will be investigated in Sect. 3.3.

\subsection{Long-range transport mechanism and pollutant accumulation}

It is established in the previous studies that LRT plays an important role in the AS pre-monsoon ozone pool (Lal and Lawrence, 2001; Chand et al., 2003; Srivastava et al., 2011, 2012; Lal et al., 2013, 2014). Trajectory models are used to investigate the LRT pathways of the air parcels. Figures 6 and 7 show an example of the HYSPLIT backward and forward trajectory results for air masses over AS at 2, 4, 7 and $15 \mathrm{~km}$ in April 2008. In the lower troposphere $(0-8 \mathrm{~km})$, the sources are identified as the Middle East, India and northern Africa, which are consistent with the previous studies. The higher tropospheric ozone $(12-18 \mathrm{~km})$ is found in air which was uplifted and transported not only from the northern Africa but also from the northern Indian Ocean and southeastern Asia. The air masses in the lower troposphere subside 4$5 \mathrm{~km}$ locally within a high-pressure system within 10 days. This confirms the conclusion on accumulation of a pollutant which was derived from the wind field information in
Sect. 3.1 (see Fig. 5). This theory was also proved by Srivastava et al. (2011) from the TPSCF (total potential source contribution function) results. One explanation for the larger TOC over the AS in comparison to surrounded regions is the lower humidity which provides less favourable condition for ozone depletion by hydroxyl radicals $(\mathrm{OH})$. This is further discussed in Sect. 3.3. In addition to the sources, here we also investigate the areas that are influenced by the AS ozone pool (Fig. 7). The ozone-rich air over the AS is transported back to India (lower left panel). HYSPLIT also simulates transport to the Red Sea through the Gulf of Aden in the lower troposphere (upper panels), which is expected because of the mountains aside acting as a barrier for pollution transport. The elevated tropospheric air masses are also transported towards the Pacific Ocean via China (lower right panel).

To quantify contributions to LRT from different source locations, the tagged tracer simulation with MOZART-4 CTM (Sudo and Akimoto, 2007; Hou et al., 2014) during 19972007 was used. Figure 8 shows the seven tagged regions. Europe, Africa and the Middle East are combined into one hotspot as the closer western region (named "Euro"). India, Bay of Bengal and AS are presented together as the closer eastern region (named "India"). Note that when evaluating the contribution from this region, the influence from pollutant accumulation over the AS should always be considered. 
NOAA HYSPLIT model

Backward trajectories ending at 10:00 UTC 20 Apr 2008

GDAS meteorological data
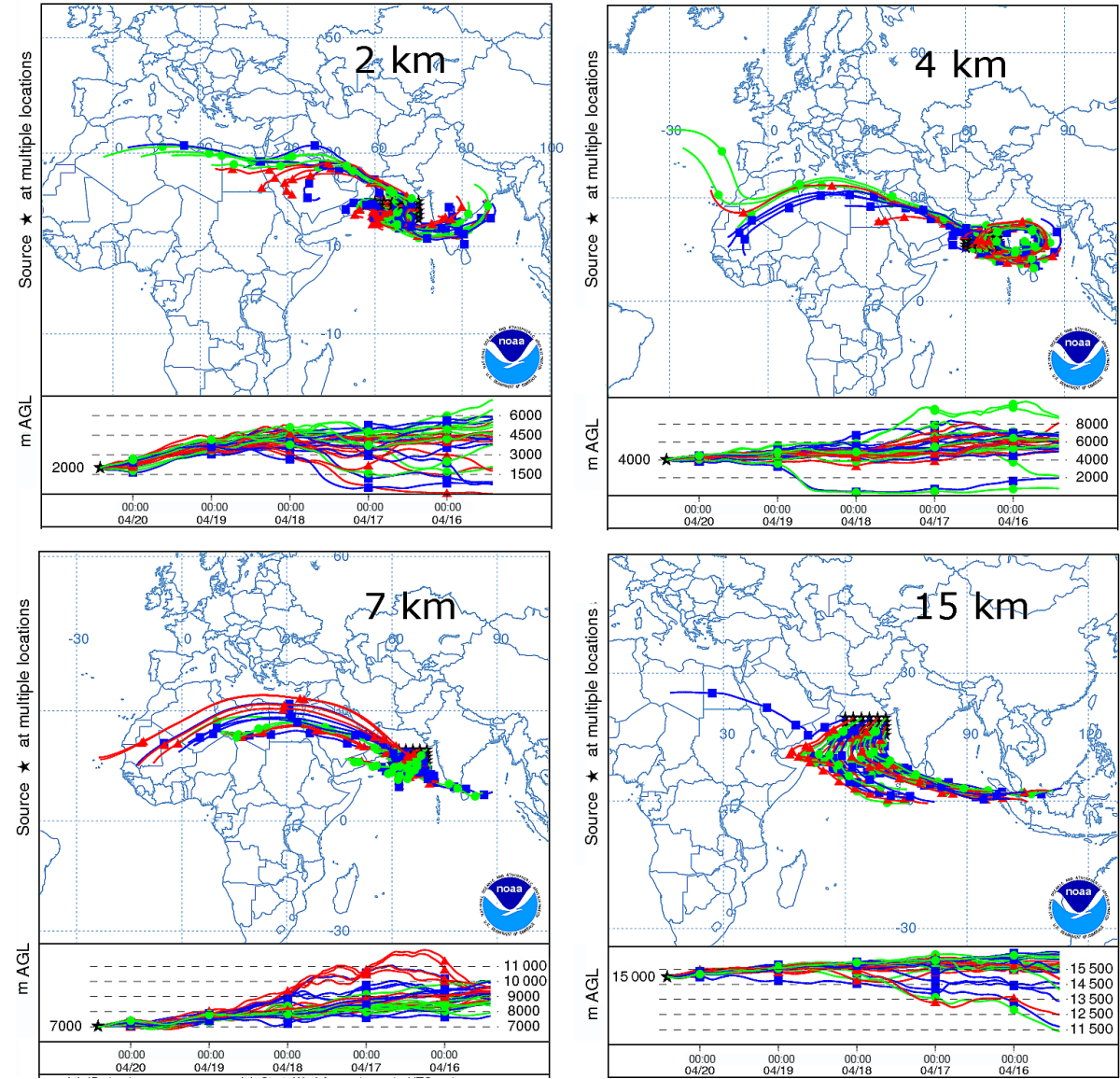

Figure 6. HYSPLIT trajectory $120 \mathrm{~h}$ backward model results for air masses at AS with source location at 2, 4, 7 and $15 \mathrm{~km}$.

The Indian Ocean is included in the "Rest" region. "NA" and "SA" represent North America and South America, respectively. The selected names are rather symbolic and do not pretend to be geographically fully correct. The regions are divided due to the time consumption of the model calculation. For further studies, another arrangement can be considered.

The source region distribution varies for different altitude ranges (Fig. 9). The percentage contributions from different regions are calculated by first estimating the ozone concentration (in ppbv) from a separated region using tagged tracer method (Sudo and Akimoto, 2007), then dividing this value by the sum of ozone concentrations. In the $0-4 \mathrm{~km}$ layer, $\sim 30 \%$ of the transported ozone comes from the "Euro" region. The "India" region is the biggest source region, contributing $50 \%$, of which $60 \%$ comes from the boundary layer. In the 4-8 km layer, the influences of the boundary layers are much smaller, while "Euro_FT" contributes $\sim 10 \%$ more than to the $0-4 \mathrm{~km}$ layer. The far-away source regions ("NA", "SA" and "IndoA") become non-negligible ( $10 \%$ each). The contribution from "IndoA" increases with height.
Since the Indian Ocean is included, an increased contribution from "Rest" with altitude is expected. In conclusion, the main contributor to LRT is "Euro_FT' with $30 \%$ contribution on average, followed by the "India" region with over $20 \%$ contribution. Since "Euro_FT" is the major source of TOC over AS, higher TOCs are observed over the western AS, which is close to southwestern Asia, i.e., Oman, Yemen, Pakistan, etc., instead of the eastern AS near west coast of India. The inputs from far-away source regions are similar, with $\sim 10 \%$ each. The influence from eastern Asia is negligible. Note that the air masses in the higher altitudes are normally quickly removed by the strong advection (Fig. 10). The contributors in the lower altitudes $(<12 \mathrm{~km})$ have more influences on the ozone accumulation.

\subsection{Local chemistry}

This section addresses two questions: (1) what is the role of the photochemistry for TOC above AS? (2) Is more ozone been photochemically produced during the long accumula- 


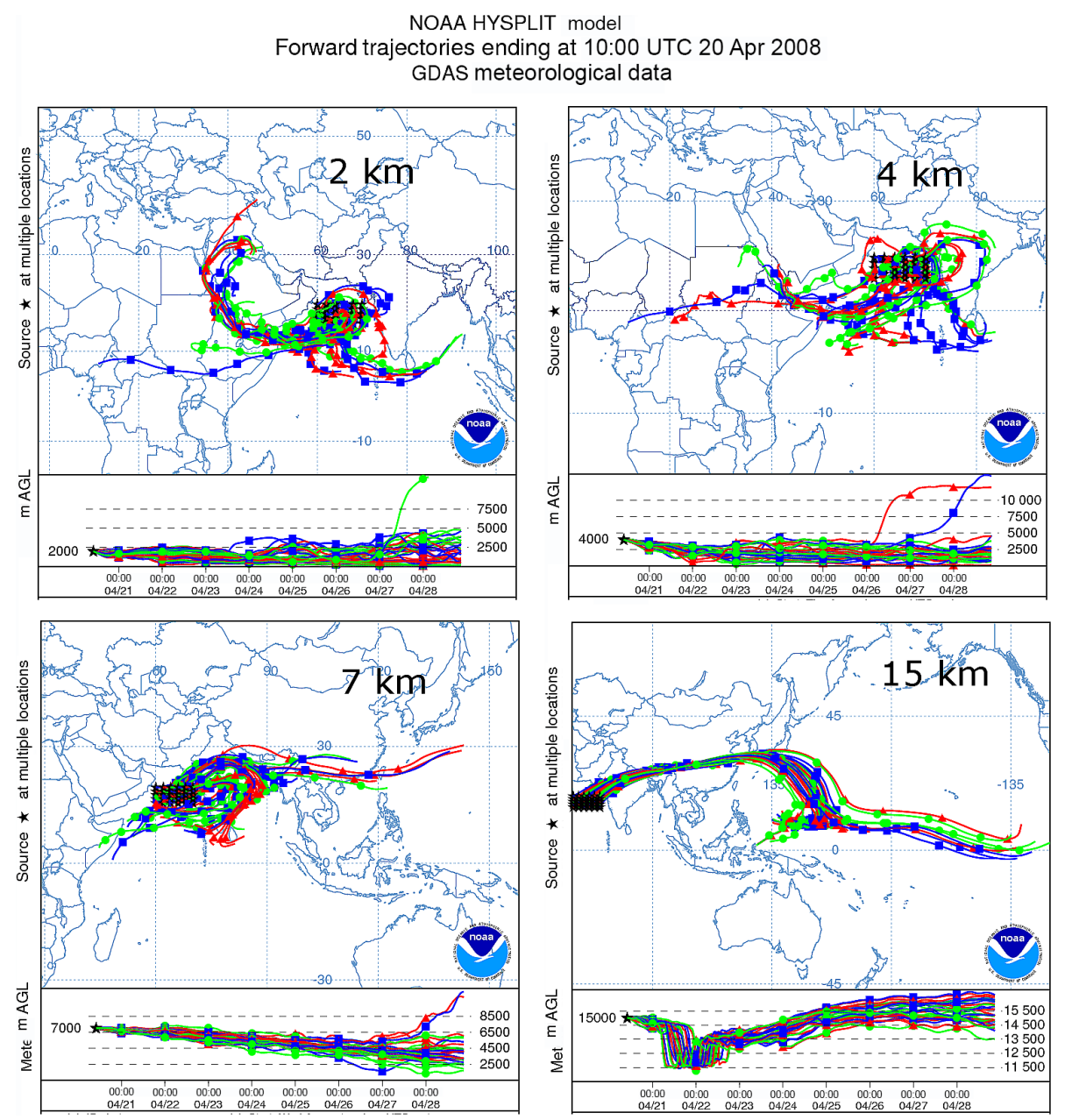

Figure 7. HYSPLIT trajectory $240 \mathrm{~h}$ forward model results for air masses at AS with source location at 2, 4, 7 and $15 \mathrm{~km}$.

Tagging $\mathrm{O}_{3}$ regions

NO emissions spring climate average

$\mu \mathrm{g} \mathrm{m} \mathrm{s}^{-1}$

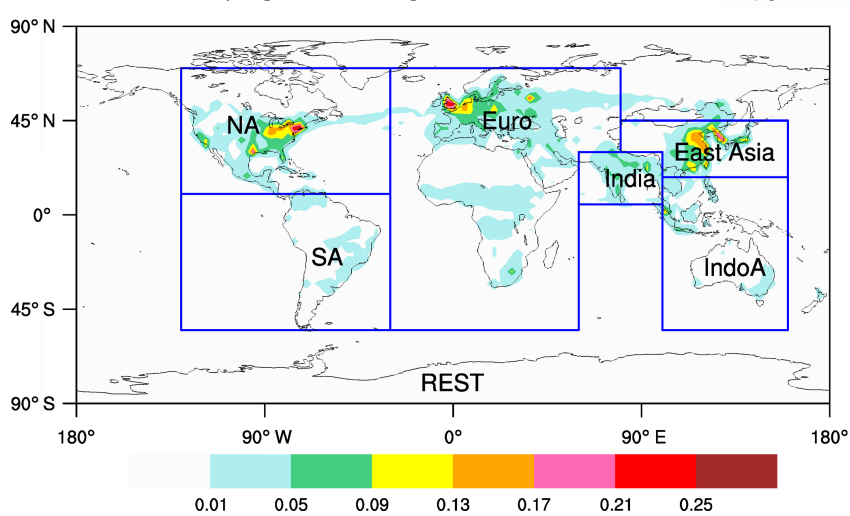

Figure 8. Regional separation for tracer tagging with distributions of the spring mean emission rate $\left(\mu \mathrm{g} \mathrm{m}^{-2} \mathrm{~s}^{-1}\right)$ of $\mathrm{NO}$ (including anthropogenic, biomass burning, and soil emissions) at the surface used in the model simulations during 1997-2007. tion time in the middle $(4-8 \mathrm{~km})$ or lower $(0-4 \mathrm{~km})$ troposphere?

The ozone budget is calculated in the MOZART-4 model (Fig. 10) within the 1997-2007 time periods. Photochemistry plays a very different role in the four altitude ranges. In the $0-4 \mathrm{~km}$ layer, water vapour acts as a source of $\mathrm{OH}$ radicals and depletes ozone. Compared to the photochemical production, this depletion process dominates (Nair et al., 2011). Thus, a net outflow of ozone in chemistry was observed. In the higher layers $(8-12,12-18 \mathrm{~km})$, photochemical production becomes a major source of ozone, while advection is the major sink. By using the CARIBIC (Civil Aircraft for the Regular Investigation of the atmosphere Based on an Instrumented Container) aircraft data from 10-11 km altitude, Zahn et al. (2002) estimated that the annual net ozone production rates over AS are $17.6 \times 10^{10}$ molecules $\mathrm{cm}^{-2} \mathrm{~s}^{-1}$. However, Livesey et al. (2013) showed in MLS data that such a maximum of ozone amount around $215 \mathrm{hPa}(\sim 11 \mathrm{~km})$ in pre-monsoon season is most likely a zonal pattern. In the 4 $8 \mathrm{~km}$ layer, the budget is rather small with a net inflow by 

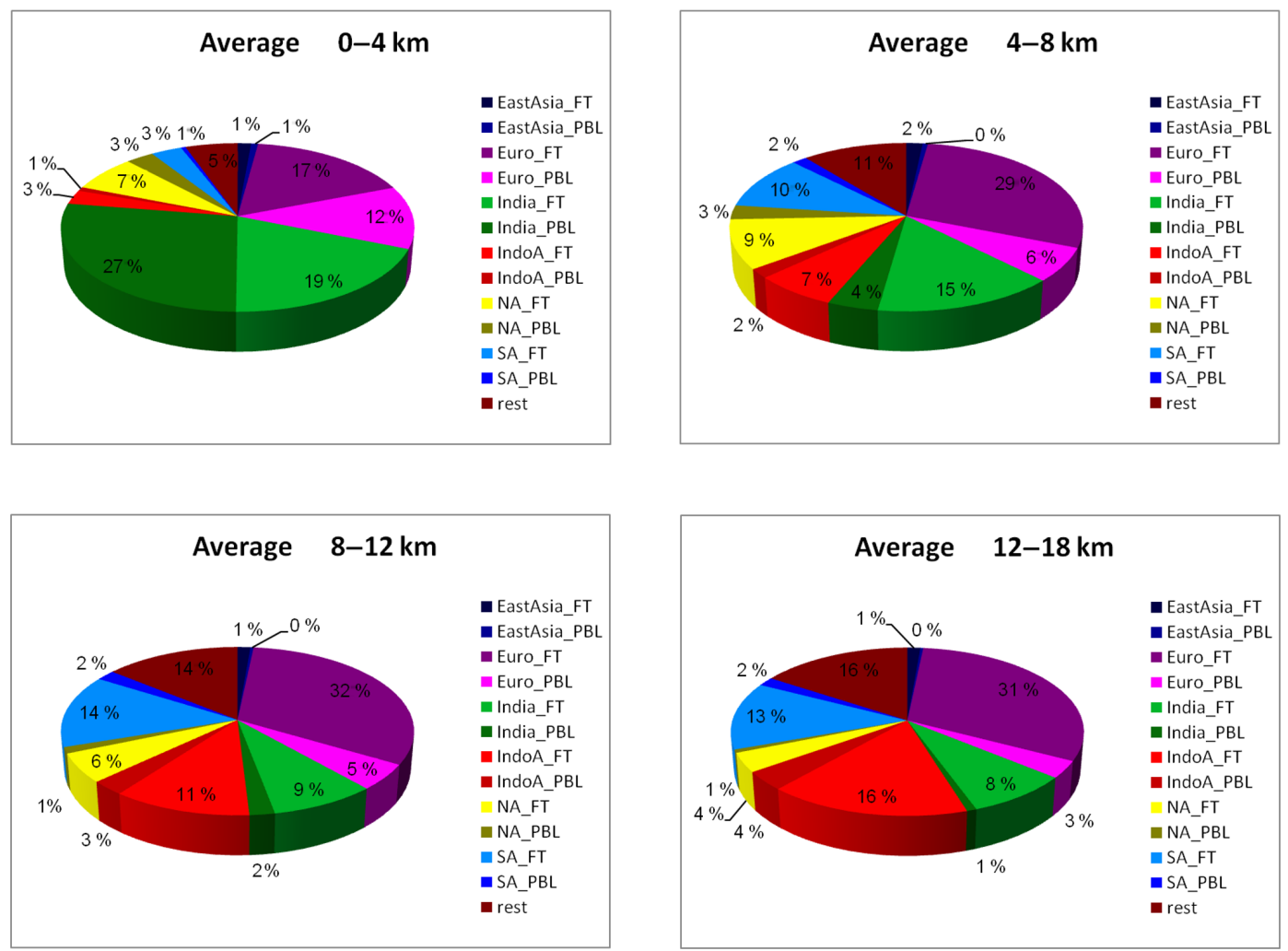

Figure 9. Averaged LRT contributions to the AS tropospheric ozone concentration from different source regions to four atmospheric layers over the AS in April 1997-2007. PBL (planetary boundary layer) is defined as the region from surface to the top of the boundary layer. FT (free troposphere) is defined as extending to the tropopause above the BL.

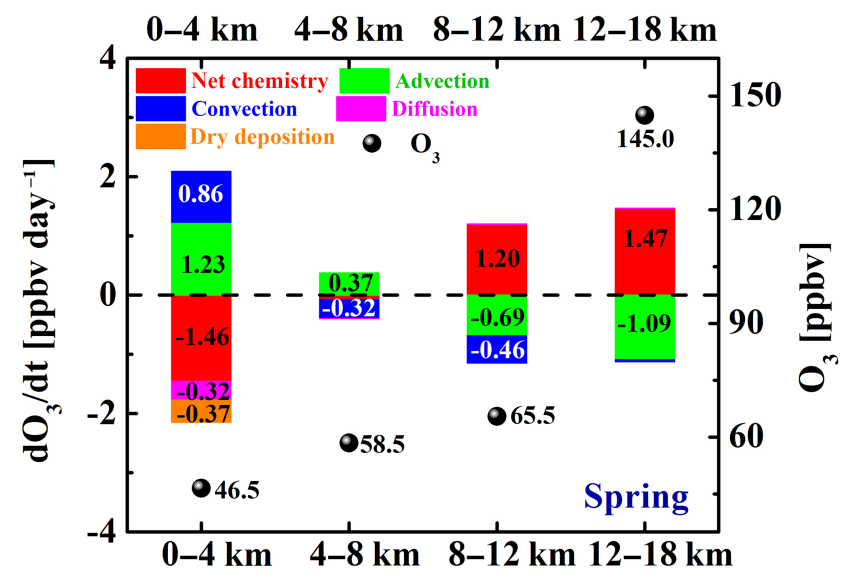

Altitude [km]

Figure 10. Averaged ozone budget in pre-monsoon from MOZART-4 at four layers over AS region. The ozone partial column volumes (ppbv) calculated from MOZART-4 is presented as black dots. advection. The net chemistry is less than -0.1 ppbv per day, indicating a negligible sink.

The $\mathrm{O}_{3}-\mathrm{CO}$ correlation has been broadly used to indicate tropospheric $\mathrm{O}_{3}$ sources (Fishman and Seiler, 1983; Kim et al., 2013; Inness et al., 2015). A positive $\mathrm{O}_{3}-\mathrm{CO}$ correlation denotes considerable chemical production of $\mathrm{O}_{3}$. A negative correlation, on the other hand, can originate from chemical $\mathrm{O}_{3}$ loss or deposition, or can suggest that the air mass is either transported from the stratosphere or moved by advection from the free troposphere. Figure 11 shows the $\mathrm{O}_{3}-\mathrm{CO}$ correlation at $4-8 \mathrm{~km}$ in April using MACC data. The left panel is a typical correlation result with strong negative correlations over AS (see also Appendix Fig. A1). This correlation suggests that a chemical production of ozone is most likely not the cause for the observed ozone enhancement. Some ozone production is expected (e.g., year 2006 in the right panel), but this kind of situation is rare.

The averaged specific humidity between 4 and $8 \mathrm{~km}$ was used to investigate evidence for the impact of $\mathrm{HO}_{x}$ removal on ozone in clean air conditions (Fig. 12):

$$
\begin{aligned}
& \mathrm{OH}+\mathrm{CO}+\mathrm{O}_{2} \rightarrow \mathrm{HO}_{2}+\mathrm{CO}_{2} \\
& \frac{\mathrm{HO}_{2}+\mathrm{O}_{3} \rightarrow \mathrm{OH}+2 \mathrm{O}_{2}}{\text { Net }: \mathrm{CO}+\mathrm{O}_{3} \rightarrow \mathrm{CO}_{2}+\mathrm{O}_{2} .}
\end{aligned}
$$



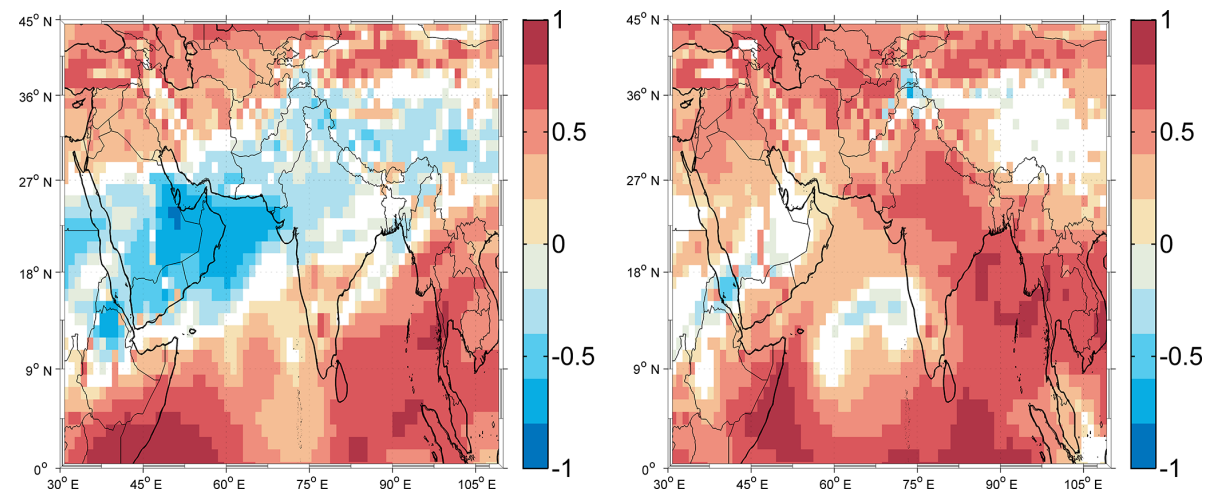

Figure 11. $\mathrm{O}_{3}-\mathrm{CO}$ correlations calculated for $4-8 \mathrm{~km}$ column abundances with $3 \mathrm{~h}$ temporal interval in April 2008 (left panel) and 2006 (right panel) from MACC reanalysis data.

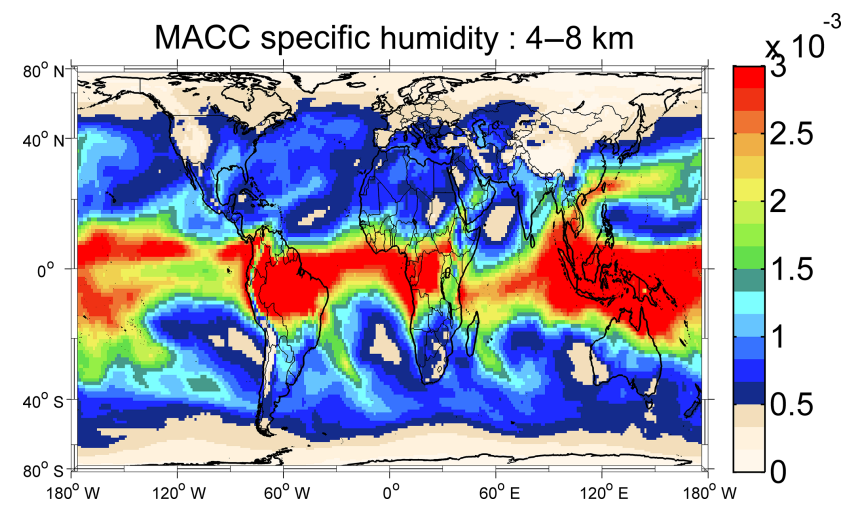

Figure 12. Specific humidity $\left(\mathrm{kg} \mathrm{kg}^{-1}\right)$ at $4-8 \mathrm{~km}$ in April 2006 from MACC reanalysis data set.

Unlike the humid lowest troposphere, the air masses over the AS at $4-8 \mathrm{~km}$ are rather dry compared to the surroundings. This can be explained by adiabatic lifting and expansion of marine boundary air followed by condensation and removal for $\mathrm{H}_{2} \mathrm{O}$. The lifting is stronger over land than over ocean due to the temperature differences. This is also one of the reasons that southeastern Asia has strongest convection. The dry air at $4-8 \mathrm{~km}$ can lead to a smaller depletion contribution from $\mathrm{OH}$ radicals, and thus it is more suitable for ozone accumulation. Hence, the AS ozone columns in the 4-8 km altitude region are expected to be higher than its surroundings.

\subsection{Stratosphere-troposphere exchange}

The STE is not the focus of this study and is thus only briefly mentioned here. The ozone concentrations in the extra-tropical lower stratosphere show a maximum in late winter/early spring as driven by the Brewer-Dobson circulation (e.g., Fortuin and Kelder, 1998; Metz et al., 2005). Fadnavis et al. (2010) indicated ozone stratospheric intrusion during winter and pre-monsoon season over the Indian re-

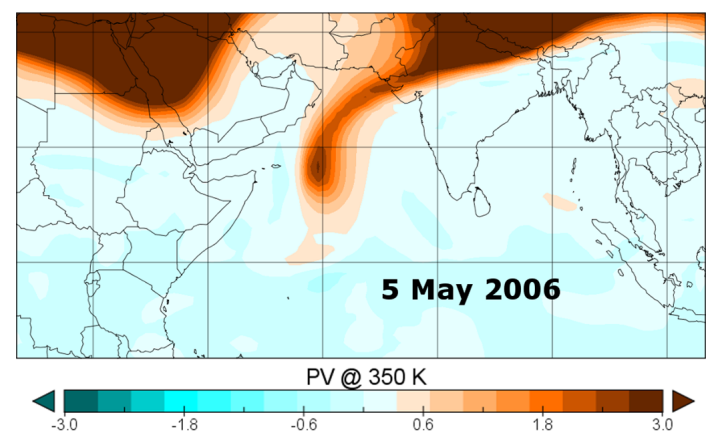

Figure 13. Potential vorticity from ECMWF.

gion $\left(5-40^{\circ} \mathrm{N}, 65-100^{\circ} \mathrm{E}\right)$ by using both satellite and model data. One stratospheric intrusion was observed over AS during the ICARB campaign (Lal et al., 2013) on 5 May 2006 (Fig. 13). However, it is not clear yet how much and how great the influence can be. In our study, the STE contribution simulated by MOZART-4 tagged tracer method is comparable with the ones transported from "Euro_FT" in most altitude ranges (STE to "Euro_FT" contributions are 0.955 at $0-4 \mathrm{~km}, 0.861$ at $4-8 \mathrm{~km}, 0.997$ at $8-12 \mathrm{~km}$, and 16.858 at $12-18 \mathrm{~km})$. The STE origin might be a reason for the strong negative $\mathrm{O}_{3}-\mathrm{CO}$ correlation since the chemical loss and deposition are excluded (Sect. 3.3).

\section{ENSO and interannual variation}

Two spring anomalies are depicted in 2005 and 2010 where ozone is $\sim 5$ DU lower compared to other years (upper panel of Fig. 3). The decrease in 2010 is most likely to be the anomaly of the lower troposphere ozone as observed in Fig. 4. The two following facts suggest the anomaly to be dynamical: (1) the ozone reduced by a similar amount at continental surroundings and (2), similar to ozone, a lower CO maximum appeared in 2010 (lower panel of Fig. 3). 


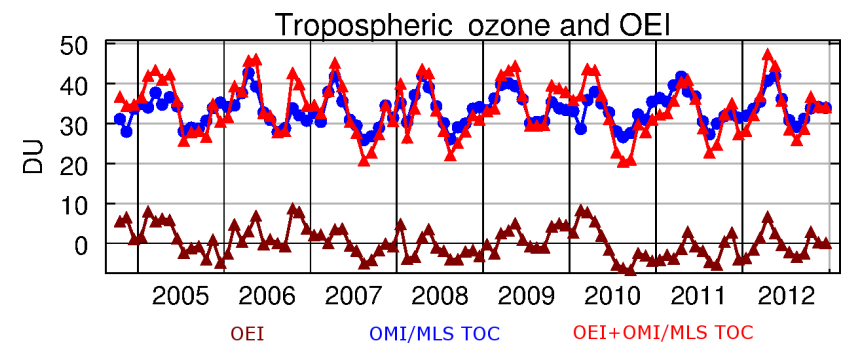

Figure 14. Time series of tropospheric ozone columns "corrected" with OEI over AS $\left(10-20^{\circ} \mathrm{N}, 60-70^{\circ} \mathrm{E}\right)$ from 2004 to 2012 . The blue curve represents OMI/MLS TOCs, dark red is OEI calculated from OMI/MLS and red stands for OMI/MLS TOCs with OEI "correction".

The El Niño events, as driven by a reversal of the Walker circulation, affect the temperature, humidity and biomass burning emissions, thus influencing the trace gases including ozone. Particularly, the tropospheric ozone anomaly related to the El Niño event during the year 1997-1998 was intensively studied (e.g. Chandra et al., 1998; Sudo and Takahashi, 2001). The tropospheric ozone increased (up to 25 DU in the burning season) over the equatorial western Pacific due to a reduced convection and growing burning emissions, whereas it decreased (4-8 DU) over the eastern Pacific because of the change in meteorological conditions. By using a model simulation, Zeng and Pyle (2005) reported that the tropospheric ozone concentration at specifically the equatorial region 40 $70^{\circ} \mathrm{E}$ decreases by a similar amount to that over the eastern Pacific during El Niño events. Ziemke et al. (2010) showed that the ENSO-related response of tropospheric ozone over the western and eastern Pacific dominated interannual variability. An ozone ENSO index (OEI) was formed to represent the ENSO impact. The OEI was calculated by subtracting the eastern and central tropical Pacific region total ozone $\left(15^{\circ} \mathrm{S}-\right.$ $\left.15^{\circ} \mathrm{N}, 110-180^{\circ} \mathrm{W}\right)$ from the western tropical Pacific-Indian Ocean region $\left(15^{\circ} \mathrm{S}-15^{\circ} \mathrm{N}, 70-140^{\circ} \mathrm{E}\right)$, with the fact that the zonal variability in tropical stratospheric ozone is only $\sim 1$ DU.

Figure 14 shows the OEI that is produced from OMI/MLS data for the related time period (dark red curve). A "correction" of OMI/MLS TOCs over the AS by adding the OEI is performed. The ozone spring maxima anomalies at premonsoon season in 2005 and 2010 (blue curve) can no longer be seen after the "correction". This indicates that the El Niñoinduced dynamics might contribute to the interannual variability over pre-monsoon AS ozone. Since OEI contains both chemical (fire) and dynamical influences in the burning season, ozone peaks (in the red curve) can be observed in the winter of 2006 and 2009, when strong fires happened in Indonesia.

The dynamical influence of El Niño can be found in two aspects. El Niño can induce an increase in sea surface temperature (SST), thus strengthening the water vapour up- welling to the middle troposphere, and then reducing the lifetime of ozone. It also possibly triggers changes in STE flux as mentioned by, for example, Neu et al. (2014). Moister air masses are observed from MACC reanalysis data in April 2010 (Appendix Fig. A2). This confirms the assumption of the SST influence over AS. A STE flux variation can be caused by both El Niño and La Niña events. In this case La Niña events (in 2011) did not contribute as much as El Niño events (in 2005 and 2010). The impact of El Niño is mainly expressed by the SST anomaly instead of the STE anomaly.

\section{Conclusions}

The 7-year composite averaged values for TOC presented over AS exhibit a seasonal pattern and have values similar to those in the southern hemispheric biomass burning plume. A disciplined tropospheric ozone seasonality with a $\sim 42$ DU maximum at the pre-monsoon season was shown in the satellite-based OMI/MLS and TES observations as well as in the MACC reanalysis model. The seasonal feature is found to be strongly related to the meteorological conditions.

Previous studies illustrated the importance of LRT to the pre-monsoon ozone enhancement and confirmed the source locations to be the Middle East, western India, Africa, North America and Europe. Here various regional contributions to the AS pre-monsoon ozone through LRT were analysed by dividing the global range into seven regions using the MOZART-4 tagging tracer simulation method. In the lowest $4 \mathrm{~km}$, the sources from India contributed $\sim 50 \%$ of the transported AS ozone amount. The free troposphere of the Middle East, Africa and Europe (so-called "Euro_FT") started to play a major role from $4 \mathrm{~km}$ altitude and higher. The contribution is on average $30 \%$. The Indian region is still the second important source region at $4-8 \mathrm{~km}$ with $\sim 20 \%$. Its contribution is slowly replaced by the further-away source regions at higher altitude range. It is worth mentioning that South America plays a more important role compared to North America, yet there is no explanation for this result so far.

In addition, the vertical pollutant accumulation in the lower troposphere, especially at $4-8 \mathrm{~km}$, is important to the AS spring ozone pool. The suitable meteorological conditions were discovered from wind field data from NCEP and specific humidity data from MACC. First, the cloud-free anticyclonic condition that is observed from the wind field data can cause air to be transported upside down. This point is supported by the forward model results of HYSPLIT showing that, at $\sim 7 / 8 \mathrm{~km}$ or lower, the air circles down over the AS region for around 10 days without diffusion. Second, at 4-8 km the air over AS is much drier than the surroundings. This is most probably due to relatively lower temperature over the sea which caused that the moisture cannot be lifted up as high as over land. The dry conditions induce the accumulation of ozone with a longer lifetime, thus causing the AS 
ozone to be outstanding $\sim 2-3$ DU higher than the amount in the subcontinental regions as shown in the satellite data.

The averaged spring ozone budget was calculated using MOZART-4 to improve our understanding of the additional local chemical activity. Ozone is photochemically produced at high altitudes $(8-18 \mathrm{~km})$ and is removed by advection. In the lowest $4 \mathrm{~km}$, ozone is depleted by $\mathrm{OH}$ radicals. Positive ozone budgets from advection and convection can be observed, which supported the LRT and accumulation mechanisms. At 4-8 km, despite the weak ozone destruction from $\mathrm{OH}$ radicals, the net chemical budget is negligible. This suggests a low photochemical production, which is also supported by the negative $\mathrm{O}_{3}-\mathrm{CO}$ correlation. According to the simulation results and the $\mathrm{O}_{3}-\mathrm{CO}$ correlation, a net contribution from STE can also influence the local ozone amount.

The two spring ozone interannual anomalies are believed to be influenced by the dynamical variations (SST anomaly) during the El Niño events. The climate interacts with the distribution of tropospheric ozone through temperature, humidity and dynamics.

Data availability. Data used in this publication can be accessed by contacting the corresponding author or the responsible co-authors. 


\section{Appendix A}

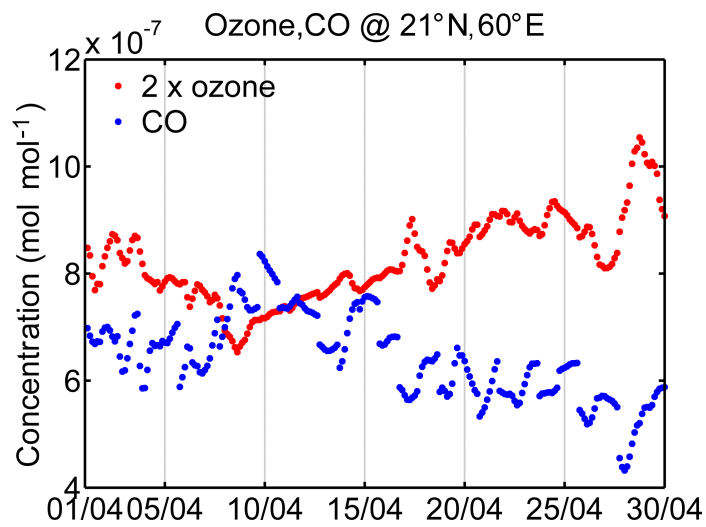

Figure A1. $\mathrm{O}_{3}$ and $\mathrm{CO}$ partial column (4-8 km) time series at $21^{\circ} \mathrm{N}, 60^{\circ} \mathrm{E}$ over AS at April 2008 from MACC reanalysis data. The plot is a "point" example of Fig. 10.

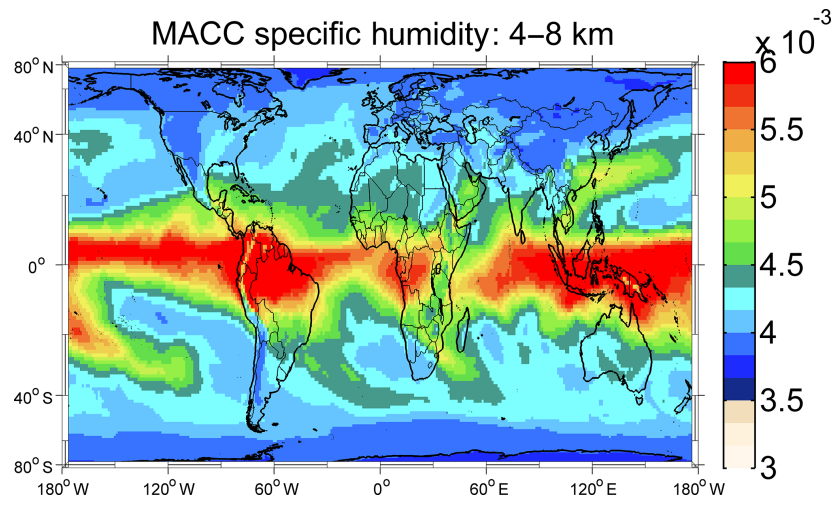

Figure A2. Same as Fig. 12 but for the year 2010.

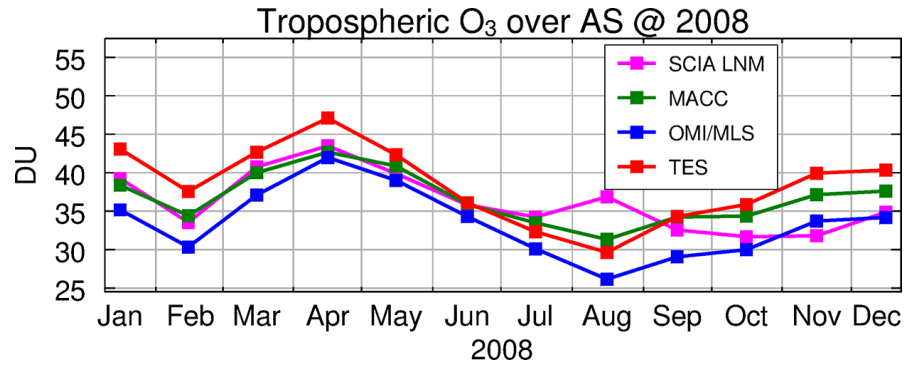

Figure A3. TOC results over AS from SCIAMACHY Limb-Nadir-Matching, OMI/MLS, TES, and MACC reanalysis data sets in 2008. 
Competing interests. The authors declare that they have no conflict of interest.

Acknowledgements. We would like to thank the SCIAMACHY LNM NO 2 , OMI/MLS, TES tropospheric ozone, IASI CO and teams for providing the data. We acknowledge the two working groups of MACC reanalysis, NCEP, and MOZART-4. Jia Jia acknowledges funding by the CSC (China Scholarship Council) and scientific support from ESSReS (Earth System Science Research School). We also acknowledge financial support provided by the University and State of Bremen. We would like to thank Anne-Marlene Blechschmidt for her help. Our gratitude goes to Christian von Savigny for giving comments during the preparation of the manuscript. The authors acknowledge the North-German Supercomputing Alliance (HLRN) for providing HPC resources that have contributed to the research results reported in this paper.

The article processing charges for this open-access publication were covered by the University of Bremen.

Edited by: A. Hofzumahaus

Reviewed by: three anonymous referees

\section{References}

Ali, K., Beig, G., Chate, D. M., Momin, G. A., Sahu, S. K., and Safai, P. D.: Sink mechanism for significantly low level of ozone over the Arabian Sea during monsoon, J. Geophys. Res., 114, D17306, doi:10.1029/2008JD011256, 2009.

Beer, R.: TES on the Aura mission: Scientific objectives, measurements, and analysis overview, IEEE T. Geosci. Remote, 44, 1102-1105, 2006.

Beer, R., Glavich, T. A., and Rider, D. M.: Tropospheric emission spectrometer for Earth Observing System's Aura satellite, Appl. Optics, 40, 2356-2367, 2001.

Beirle, S., Boersma, K. F., Platt, U., Lawrence, M. G., and Wagner, T.: Megacity emissions and lifetimes of nitrogen oxides probed from space, Science, 333, 1737-1739, doi:10.1126/science.1207824, 2011.

Bovensmann, H., Burrows, J. P., Buchwitz, M., Frerick, J., Noël, S., Rozanov, V. V., Chance, K. V., and Goede, A. P. H.: SCIAMACHY: mission objectives and measurement modes, J. Atmos. Sci., 56, 127-150, 1999.

Burrows, J. P., Hölzle, E., Goede, A., Visser, H., and Fricke, W.: SCIAMACHY - scanning imaging absorption spectrometer for atmospheric chartography, Acta Astronaut., 35, 445-451, 1995.

Chand, D., Lal, S., and Naja, M.: Variations of ozone in the marine boundary layer over the Arabian Sea and the Indian Ocean during the 1998 and 1999 INDOEX campaigns, J. Geophys. Res., 108, 4190, doi:10.1029/2001JD001589, 2003.

Chandra, S., Ziemke, J. R., Min, W., and Read, W. G.: Effects of 1997-1998 El Niño on tropospheric ozone, Geophys. Res. Lett., 25, 3867-3870, 1998.

David, L. M. and Nair, P. R.: Tropospheric column $\mathrm{O}_{3}$ and $\mathrm{NO}_{2}$ over the Indian region observed by Ozone Monitoring Instrument (OMI): seasonal changes and long-term trends, Atmos. Environ., 65, 25-39, doi:10.1016/j.atmosenv.2012.09.033, 2013.
Dickerson, R. R., Rhoads, K. P., Carsey, T. P., Oltmans, S. J., Burrows, J. P., and Crutzen, P. J.: Ozone in the remote marine boundary layer: a possible role for halogens, J. Geophys. Res., 104, 21385-21395, 1999.

Duncan, B. N., Martin, R. V., Staudt, A. C., Yevich, R., and Logan, J. A.: Interannual and seasonal variability of biomass burning emissions constrained by satellite observations, J. Geophys. Res., 108, 4100, doi:10.1029/2002JD002378, 2003.

Ebojie, F., von Savigny, C., Ladstätter-Weißenmayer, A., Rozanov, A., Weber, M., Eichmann, K.-U., Bötel, S., Rahpoe, N., Bovensmann, H., and Burrows, J. P.: Tropospheric column amount of ozone retrieved from SCIAMACHY limb-nadir-matching observations, Atmos. Meas. Tech., 7, 2073-2096, doi:10.5194/amt-72073-2014, 2014.

Emmons, L. K., Walters, S., Hess, P. G., Lamarque, J.-F., Pfister, G. G., Fillmore, D., Granier, C., Guenther, A., Kinnison, D., Laepple, T., Orlando, J., Tie, X., Tyndall, G., Wiedinmyer, C., Baughcum, S. L., and Kloster, S.: Description and evaluation of the Model for Ozone and Related chemical Tracers, version 4 (MOZART-4), Geosci. Model Dev., 3, 43-67, doi:10.5194/gmd3-43-2010, 2010.

Fadnavis, S., Chakraborty, T., and Beig, G.: Seasonal stratospheric intrusion of ozone in the upper troposphere over India, Ann. Geophys., 28, 2149-2159, doi:10.5194/angeo-28-2149-2010, 2010.

Fishman, J. and Seiler, W.: Correlative nature of ozone and carbon monoxide in the troposphere: Implications for the tropospheric ozone budget, J. Geophys. Res., 88, 3662-3670, doi:10.1029/JC088iC06p03662, 1983.

Fishman, J., Minnis, P., and Reichle Jr., H. G.: The use of satellite data to study tropospheric ozone in the tropics, J. Geophys. Res., 91, 14451-14465, 1986.

Fishman, J., Fakhruzzaman, K., Cros, B., and Nganga, D.: Identification of widespread pollution in the Southern Hemisphere deduced from satellite analyses, Science, 252, 1693-1696, 1991.

Fortuin, J. P. F. and Kelder, H.: An ozone climatology based on ozonesonde and satellite measurements, J. Geophys. Res., 103, 31709-31734, 1998.

George, M., Clerbaux, C., Hurtmans, D., Turquety, S., Coheur, P.F., Pommier, M., Hadji-Lazaro, J., Edwards, D. P., Worden, H., Luo, M., Rinsland, C., and McMillan, W.: Carbon monoxide distributions from the IASI/METOP mission: evaluation with other space-borne remote sensors, Atmos. Chem. Phys., 9, 8317-8330, doi:10.5194/acp-9-8317-2009, 2009.

Hilboll, A., Richter, A., and Burrows, J. P.: Long-term changes of tropospheric $\mathrm{NO}_{2}$ over megacities derived from multiple satellite instruments, Atmos. Chem. Phys., 13, 4145-4169, doi:10.5194/acp-13-4145-2013, 2013.

Holton, J. R., Haynes, P. H., McIntyre, M. E., Douglass, A. R., Rood, R. B., and Pfister, L.: Stratosphere-troposphere exchange, Rev. Geophys., 33, 403-439, 1995.

Hou, X., Zhu, B., Kang, H., and Gao, J.: Analysis of seasonal ozone budget and spring ozone latitudinal gradient variation in the boundary layer of the Asia-Pacific region, Atmos. Environ., 94, 734-741, doi:10.1016/j.atmosenv.2014.06.006, 2014.

Inness, A., Baier, F., Benedetti, A., Bouarar, I., Chabrillat, S., Clark, H., Clerbaux, C., Coheur, P., Engelen, R. J., Errera, Q., Flemming, J., George, M., Granier, C., Hadji-Lazaro, J., Huijnen, V., Hurtmans, D., Jones, L., Kaiser, J. W., Kapsomenakis, J., Lefever, K., Leitão, J., Razinger, M., Richter, A., Schultz, M. G., 
Simmons, A. J., Suttie, M., Stein, O., Thépaut, J.-N., Thouret, V., Vrekoussis, M., Zerefos, C., and the MACC team: The MACC reanalysis: an $8 \mathrm{yr}$ data set of atmospheric composition, Atmos. Chem. Phys., 13, 4073-4109, doi:10.5194/acp-13-4073-2013, 2013.

Inness, A., Benedetti, A., Flemming, J., Huijnen, V., Kaiser, J. W., Parrington, M., and Remy, S.: The ENSO signal in atmospheric composition fields: emission-driven versus dynamically induced changes, Atmos. Chem. Phys., 15, 9083-9097, doi:10.5194/acp-15-9083-2015, 2015.

Jia, J.: Improvement and interpretation of the tropospheric ozone columns retrieved based on SCIAMACHY Limb-Nadir Matching approach, PhD thesis, http://nbn-resolving.de/urn:nbn:de: gbv:46-00105374-15, University of Bremen, Bremen, Germany, 2016.

Kim, P. S., Jacob, D. J., Liu, X., Warner, J. X., Yang, K., Chance, K., Thouret, V., and Nedelec, P.: Global ozone-CO correlations from OMI and AIRS: constraints on tropospheric ozone sources, Atmos. Chem. Phys., 13, 9321-9335, doi:10.5194/acp-13-93212013, 2013.

Lal, S. and Lawrence, M. G.: Elevated mixing ratios of surface ozone over the Arabian Sea, Geophys. Res. Lett., 28, 1487-1490, doi:10.1029/2000GL011828, 2001.

Lal, S., Venkataramani, S., Srivastava, S., Gupta, S., Mallik, C., Naja, M., Sarangi, T., Acharya, Y. B., and Liu, X.: Transport effects on the vertical distribution of tropospheric ozone over the tropical marine regions surrounding India, J. Geophys. Res.Atmos., 118, 1513-1524, doi:10.1002/jgrd.50180, 2013.

Lal, S., Venkataramani, S., Chandra, N., Cooper, O. R., Brioude, J., and Naja, M.: Transport effects on the vertical distribution of tropospheric ozone over western India, J. Geophys. Res.-Atmos., 119, 10012-10026, doi:10.1002/2014JD021854, 2014.

Lawrence, M. G. and Lelieveld, J.: Atmospheric pollutant outflow from southern Asia: a review, Atmos. Chem. Phys., 10, $11017-$ 11096, doi:10.5194/acp-10-11017-2010, 2010.

Lelieveld, J. and Crutzen, P. J.: Influences of cloud photochemical processes on tropospheric ozone, Nature, 343, 227-233, 1990.

Levelt, P. F., van den Oord, G. H. J., Dobber, M. R., Mälkki, A., Visser, H., de Vries, J., Stammes, P., Lundell, J., and Saari, H.: The Ozone Monitoring Instrument (OMI), IEEE T. Geosci. Remote, 44, 1093-1101, 2006.

Livesey, N. J., Logan, J. A., Santee, M. L., Waters, J. W., Doherty, R. M., Read, W. G., Froidevaux, L., and Jiang, J. H.: Interrelated variations of $\mathrm{O}_{3}, \mathrm{CO}$ and deep convection in the tropical/subtropical upper troposphere observed by the Aura Microwave Limb Sounder (MLS) during 2004-2011, Atmos. Chem. Phys., 13, 579-598, doi:10.5194/acp-13-579-2013, 2013.

Logan, J. Megretskaia, A., Nassar, I., R., Murray, L. T., Zhang, L., Bowman, K. W., Worden, H. M., and Luo, M.: Effects of the 2006 El Niño on tropospheric composition as revealed by data from the Tropospheric Emission Spectrometer (TES), Geophys. Res. Lett., 35, L03816, doi:10.1029/2007GL031698, 2008.

Metz, B., Kuijpers, L., Solomon, S., Andersen, S. O., Davidson, O., Pons, J., de Jager, D., Kestin, T., Manning, M., and Meyer, L. A. (Eds.): IPCC/TEAP Special Report: Safeguarding the Ozone Layer and the Global Climate System, 488 pp., Cambridge Univ. Press, Press Cambridge, UK, 2005.

Mills, G., Harmens, H., Wagg, S., Sharps, K., Hayes, F., Fowler, D., Sutton, M., and Davies, B.: Ozone impacts on vegetation in a nitrogen enriched and changing climate, Environ. Pollut., 208, 898-908, doi:10.1016/j.envpol.2015.09.038, 2016.

Monks, P. S.: A review of the observations and origins of the spring ozone maximum, Atmos. Environ., 34, 3545-3561, 2000.

Monks, P. S., Archibald, A. T., Colette, A., Cooper, O., Coyle, M., Derwent, R., Fowler, D., Granier, C., Law, K. S., Mills, G. E., Stevenson, D. S., Tarasova, O., Thouret, V., von Schneidemesser, E., Sommariva, R., Wild, O., and Williams, M. L.: Tropospheric ozone and its precursors from the urban to the global scale from air quality to short-lived climate forcer, Atmos. Chem. Phys., 15, 8889-8973, doi:10.5194/acp-15-8889-2015, 2015.

Nair, P. R., David, L. M., Girach, I. A., and George, S. K.: Ozone in the marine boundary layer of Bay of Bengal during post-winter period: spatial pattern and role of meteorology, Atmos. Environ., 45, 4671-4681, doi:10.1016/j.atmosenv.2011.05.040, 2011.

Nassar, R., Logan, J. A., Worden, H. M., Megretskaia, I. A., Bowman, K. W., Osterman, G. B., Thompson, A. M., Tarasick, D. W., Austin, S., Claude, H., Dubey, M. K., Hocking, W. K., Johnson, B. J., Joseph, E., Merrill, J., Morris, G. A., Newchurch, M., Oltmans, S. J., Posny, F., Schmidlin, F. J., Vömel, H., Whiteman, D. N., and Witte, J. C.: Validation of Tropospheric Emission Spectrometer (TES) nadir ozone profiles using ozonesonde measurements, J. Geophys. Res., 113, D15S17, doi:10.1029/2007JD008819, 2008.

Neu, J. L., Flury, T., Manney, G. L., Santee, M. L., Livesey, N. J., and Worden, J.: Tropospheric ozone variations governed by changes in stratospheric circulation, Nat. Geosci., 7, 340-344, doi:10.1038/ngeo2138, 2014.

Novelli, P. C., Masarie, K. A., and Lang, P. M.: Distributions and recent changes of carbon monoxide in the lower troposphere, $\mathrm{J}$. Geophys. Res.-Atmos., 103, 19015-19033, 1998.

Penkett, S. A., Reeves, C. E., Bandy, B. J., Kent, J. M., and Richer, H. R.: Comparison of calculated and measured peroxide data collected in marine air to investigate prominent features of the annual cycle of ozone in the troposphere, J. Geophys. Res., 103, 13377-13388, 1998.

Richter, A., Eyring, V., Burrows, J. P., Bovensmann, H., Lauer, A., Sierk, B., and Crutzen, P. J.: Satellite measurements of $\mathrm{NO}_{2}$ from international shipping emissions, Geophys. Res. Lett., 31, L23110, doi:10.1029/2004GL020822, 2004.

Srivastava, S., Lal, S., Venkataramani, S., Gupta, S., and Acharya, Y. B.: Vertical distribution of ozone in the lower troposphere over the Bay of Bengal and the Arabian Sea during ICARB-2006: Effects of continental outflow, J. Geophys. Res., 116, D13301, doi:10.1029/2010JD015298, 2011.

Srivastava, S., Lal, S., Naja, M., Venkataramani, S., and Gupta, S.: Influence of regional pollution and long range transport over Western India: analysis of ozonesonde data, Atmos. Environ., 47, 174-182, 2012.

Stein, A. F., Draxler, R. R., Rolph, G. D., Stunder, B. J. B., Cohen, M. D., and Ngan, F.: NOAA's HYSPLIT atmospheric transport and dispersion modeling system, B. Am. Meteorol. Soc., 96, 2059-2077, doi:10.1175/BAMS-D-14-00110.1, 2015.

Sudo, K. and Akimoto, H.: Global source attribution of tropospheric ozone: Long-range transport from various source regions, J. Geophys. Res., 112, D12302, doi:10.1029/2006JD007992, 2007.

Sudo, K. and Takahashi, M.: Simulation of tropospheric ozone changes during 1997-1998 El Niño: Meteorological impact on 
tropospheric photochemistry, Geophys. Res. Lett., 28, 40914094, 2001.

Van Dingenen, R., Dentener, F. J., Raes, F., Krol, M. C., Emberson, L., and Cofala, J.: The global impact of ozone on agricultural crop yields under current and future air quality legislation, Atmos. Environ., 43, 604-618, doi:10.1016/j.atmosenv.2008.10.033, 2009.

Wang, Y., Jacob, D. J., and Logan, J. A.: Global simulation of tropospheric $\mathrm{O}_{3}$-NOx-hydrocarbon chemistry: 3. Origin of tropospheric ozone and effects of nonmethane hydrocarbons, J. Geophys. Res., 103, 10757-10767, 1998.

Waters, J. W., Froidevaux, L., Harwood, R. S., Jarnot, R. F., Pickett, H. M., Read, W. G., Siegel, P. H., Cofield, R. E., Filipiak, M. J., Flower, D. A., Holden, J. R., Lau, G. K. K., Livesey, N. J., Manney, G. L., Pumphrey, H. C., Santee, M. L., Wu, D. L., Cuddy, D. T., Lay, R. R., Loo, M. S., Perun, V. S., Schwartz, M. J., Stek, P. C., Thurstans, R. P., Boyles, M. A., Chandra, K. M., Chavez, M. C., Chen, G. S., Chudasama, B. V., Dodge, R., Fuller, R. A., Girard, M. A., Jiang, J. H., Jiang, Y. B., Knosp, B. W., LaBelle, R. C., Lam, J. C., Lee, K. A., Miller, D., Oswald, J. E., Patel, N. C., Pukala, D. M., Quintero, O., Scaff, D. M., Van Snyder, W., Tope, M. C., Wagner, P. A., and Walch, M. J.: The Earth Observing System Microwave Limb Sounder (EOS MLS) on the Aura satellite, IEEE T. Geosci. Remote Sens., 44, 1075-1092, doi:10.1109/TGRS.2006.873771, 2006.

Weller, R. A., Baumgartner, M. F., Josey, S. A., Fischer, A. S., and Kindle, J. C.: Atmospheric Forcing in the Arabian Sea during 1994-1995: Observations and Comparisons with Climatology and Models, Deep-Sea Res. Pt. II, 45, 1961-1999, doi:10.1016/S0967-0645(98)00060-5, 1998.

Young, P. J., Archibald, A. T., Bowman, K. W., Lamarque, J.-F., Naik, V., Stevenson, D. S., Tilmes, S., Voulgarakis, A., Wild, O., Bergmann, D., Cameron-Smith, P., Cionni, I., Collins, W. J., Dalsøren, S. B., Doherty, R. M., Eyring, V., Faluvegi, G., Horowitz, L. W., Josse, B., Lee, Y. H., MacKenzie, I. A., Nagashima, T., Plummer, D. A., Righi, M., Rumbold, S. T., Skeie, R. B., Shindell, D. T., Strode, S. A., Sudo, K., Szopa, S., and Zeng, G.: Preindustrial to end 21 st century projections of tropospheric ozone from the Atmospheric Chemistry and Climate Model Intercomparison Project (ACCMIP), Atmos. Chem. Phys., 13, 20632090, doi:10.5194/acp-13-2063-2013, 2013.
Zahn, A., Brenninkmeijer, C. A. M., Asman, W. A. H., Crutzen, P. J., Heinrich, G., Fischer, H., Cuijpers, J. W. M., and van Velthoven, P. F. J.: Budgets of $\mathrm{O}_{3}$ and $\mathrm{CO}$ in the upper troposphere: CARIBIC passenger aircraft results 1997-2001, J. Geophys. Res., 107, 4337, doi:10.1029/2001JD001529, 2002.

Zanis, P., Hadjinicolaou, P., Pozzer, A., Tyrlis, E., Dafka, S., Mihalopoulos, N., and Lelieveld, J.: Summertime free-tropospheric ozone pool over the eastern Mediterranean/Middle East, Atmos. Chem. Phys., 14, 115-132, doi:10.5194/acp-14-115-2014, 2014.

Zeng, G. and Pyle, J. A.: Influence of El Niño Southern Oscillation on stratosphere/troposphere exchange and the global tropospheric ozone budget, Geophys. Res. Lett., 32, L01814, doi:10.1029/2004GL021353, 2005.

Zhu, B., Hou, X., and Kang, H.: Analysis of the seasonal ozone budget and the impact of the summer monsoon on the northeastern Qinghai-Tibetan Plateau, J. Geophys. Res.-Atmos., 121, 2029_ 2042, doi:10.1002/2015JD023857, 2016.

Ziemke, J. R., Chandra, S., Duncan, B. N., Froidevaux, L., Bhartia, P. K., Levelt, P. F., and Waters, J. W.: Tropospheric ozone determined from Aura OMI and MLS: Evaluation of measurements and comparison with the Global Modeling Initiative's Chemical Transport Model, J. Geophys. Res., 111, D19303, doi:10.1029/2006JD007089, 2006.

Ziemke, J. R., Chandra, S., Oman, L. D., and Bhartia, P. K.: A new ENSO index derived from satellite measurements of column ozone, Atmos. Chem. Phys., 10, 3711-3721, doi:10.5194/acp10-3711-2010, 2010.

Ziemke, J. R., Chandra, S., Labow, G. J., Bhartia, P. K., Froidevaux, L., and Witte, J. C.: A global climatology of tropospheric and stratospheric ozone derived from Aura OMI and MLS measurements, Atmos. Chem. Phys., 11, 9237-9251, doi:10.5194/acp11-9237-2011, 2011. 